\title{
Suuntana luottamus, tieto ja osallistuminen
}

KATJA MÄKINEN

MIIKA SALO

Vuoden alussa poliittinen ja journalistinen huomio kohdistui koronapandemian lisäksi Yhdysvaltojen vallanvaihtoon. Donald Trump kylvi uudelleenvalintakampanjassaan epäluottamusta presidentinvaaleja kohtaan ja pitää edelleen julkisesti yllä käsitystä Joe Bidenin voittamien vaalien vilpillisyydestä. Populistisessa politiikassa luodaan retorisin keinoin jaottelua meihin ja vihollisiin. Koko presidenttikautensa ajan Trump vahvisti kannattajiensa keskuudessa käsitystä "perinteisestä mediasta" puolueellisten valeuutisten levittäjänä. Tätä käsitystä tietyt uutiskanavat, mediayhtiöt ja muut populistiset toimijat ovat rakentaneet jo pitkään. Epäluottamus purkautui dramaattisina tapahtumina kongressin Capitol-rakennuksessa Washingtonissa, jonne Trumpia tukeneet mielenosoittajat tunkeutuivat loppiaisena juuri kun vaalitulosta oltiin vahvistamassa. Ennen tapahtumia pitämässään puheessa Trump kehotti kannattajiaan menemään Capitolille osoittamaan mieltään ja antamaan äänensä kuulua.

Presidentinvaalit ovat Yhdysvalloissa keskeinen kansalaisten osallistumisen foorumi, ja tämänkertaiset vaalit keräsivät äänestäjiä selvästi enemmän kuin koskaan. Ehdokkaiden kannattajat kävivät kiivasta ja kärkevää kamppailua sosiaalisessa mediassa omiaan kehuen ja vastustajia haukkuen. Kahden vahvan puolueen järjestelmä ruokkii polarisaatiota, mutta saa myös asiat näyttämään kaksinapaisemmilta kuin ne ovatkaan. Jatkossa republikaanipuolueen sisäinen pirstaloituminen ja demokraattipuolueessakin esiintyvä hajaannus voivat muuttaa asetelmia.

Trumpin populistinen ja uuskonservatiivinen linja huojutti kylmän sodan jälkeistä vakiintuneeksikin ajateltua maailmanpoliittista järjestystä. Vaikka Yhdysvallat Trumpin kaudella menetti monien silmissä poliittista uskottavuuttaan ja sen keskeinen asema horjui, niin samanaikaisesti Yhdysvaltojen saama huomio mediassa kasvoi entisestään. Mediassa Yhdysvaltojen poliittisen järjestelmän piirteitä käsiteltiin yksityiskohtaisesti ja puntaroitiin, kestääkö maan poliittinen järjestelmä monien kansalaisten tuntemaa epäluottamusta ja Trumpin väärinkäytöksiä. Vastaavalla selkeydellä toivoisi Suomenkin järjestelmää käsiteltävän tulevien, nyt kesäkuulle siirrettyjen kuntavaalien lähestyessä.

Epäluottamusta lietsova ja hyväksikäyttävä toimintatapa on tuntunut sosiaalisessa mediassa lisääntyneen entisestään myös Suomen kuntavaaleihin liittyen. Oikeistopopulismissa tällainen toiminta on keskeinen osa poliittista strategiaa ja sitä käytetään järjestelmällisesti, mutta toimintatapaa ja tietynlaista "trollausta" harjoittavat muidenkin poliittisten ryhmien edustajat (ks. Ampuja ja Poutanen 2020). Sosiaalisessa mediassa viljelty epäluottamus, perusteettomat epäluulot ja suoranaiset valheet voivat levitä laajalle ja niistä voi tulla totuuksia ihmisten mielissä ja jopa mediassa. Tuore esimerkki on kansanedustaja Paavo Arhinmäen Twitter-viestistä tehty ja sosiaalisessa mediassa laajasti levinnyt kuvaväärennös, johon Yleisradion Politiikkaradioohjelmassa (10.3.2021) viitattiin Arhinmäen oikeana tviittinä. Toinen ajankohtainen esimerkki on Naton tutkimuslaitos Statcomin (2021) tekemä selvitys, jonka mukaan naisministerit saavat osakseen häirintää sosiaalisessa mediassa. Tutkimuksesta käydyssä keskustelussa joidenkin 
mielissä totuudeksi näyttäisi muotoutuneen, että pääministeri Marinin kanslia on tilannut tutkimuksen ja että sen sisältö oli "ennalta päätetty". Epäluuloja ylläpitämällä tutkimuksen pätevyys ja paikkansapitävyys on kyseenalaistettu ja samalla hallitus esitetty epäluotettavana, vaikka myöhemmin kävi ilmi, että valtioneuvoston kanslia ehdotti tutkimuksen tekemistä jo Juha Sipilän hallituksen aikana (Kervinen 18.3.2021).

Keskustelunaiheita ja käsitteitä kehittyy sosiaalisessa mediassa ja ne myös siirtyvät sieltä journalistiseen mediaan ja ihmisten arkipäivän keskusteluihin. Andrew Chadwickin (2013) mukaan nykyinen mediaympäristö muodostaakin yhteenkietoutuneen kokonaisuuden, "hybridimedian", jossa sosiaalisen ja journalistisen median sisällöt kiertävät alustalta toiselle ja eri ympäristöissä toimitaan niille tyypillisten tapojen ja odotusten mukaisesti. Käsitteet ovat poliittisesti latautuneita ja niillä on ideologista sisältöä. Kuten Maria Ruotsalainen $(2017,197)$ kirjoittaa, "niillä on aikaansaavaa voimaa: sillä, kuka ottaa merkitykset haltuunsa ja pystyy ne määrittämään julkisessa keskustelussa, on väliä”. Keskustelussa käsitteet saavat erilaisia merkityksiä, jotka eivät ole neutraaleja. Tällainen käsite on esimerkiksi "cancel-kulttuuri", jota Trump heinäkuussa 2020 Mount Rushmoren muistomerkin luona pitämässään puheessa kutsui "totalitarismin todelliseksi määritelmäksi". Kulttuurista boikotointia tarkoittava ja sävyltään kielteinen "cancel-kulttuuri" levisi käyttöön erityisesti \#MeToo-liikkeen myötä ja on tullut osaksi suomalaistakin julkista keskustelua.

Hybridimediassa poliitikot voivat käyttäytyä eri tavoin ja käyttää erilaista kieltä television ajankohtaisohjelmassa, lehtihaastattelussa ja sosiaalisessa mediassa. Tuula Vaarakallion (2017, 199-201) mukaan populistiselle liikehdinnälle on ominaista kaksoispuheen kulttuuri: on rinnakkain siisti ja salonkikelpoinen tyyli laajaa yleisöä varten ja radikaali tyyli omille kannattajille. Virallinen viestintä valtajulkisuuden kautta on maltillista, ja epävirallisemmassa viestinnässä käytetään samanaikaisesti radikaalimpia sanankäänteitä. Näin asemoidutaan retorisesti sekä parlamentaariseen politiikkaan että sen ulkolaidalle. Kansalaiselta suunnistaminen monimutkaisessa mediamaisemassa ja vaihtelevien viestintämuotojen viidakossa vaatii kriittisyyttä ja kykyä arvioida tiedon luotettavuutta.

Luottamus tieteeseen on osa yhteiskunnallista luottamusta, ja tieteen ja tiedon vapaus osa demokratiaa. Tiede ja tutkimus tarjoavat vastalääkettä karkeita yleistyksiä tekeville ja vastakkainasettelua synnyttäville populistisille virtauksille ja luovat siten mahdollisuuksia moniääniselle keskustelulle ja demokratialle. Silti nekään eivät ole suojassa epäluottamuksen kylvämiseltä eivätkä edes vihapuheelta. Vuoden tiedekirjaksi vastikään valittu Esa Väliverrosen ja Kai Ekholmin (2020) toimittama Tieteen vapaus ja tutkijan sananvapaus puolustaa tutkimuksen vapautta ja sananvapautta tilanteessa, jossa yhteiskunnallisen ilmapiirin kiristyminen ja polarisaatio ovat tehneet tutkimustiedon kyseenalaistamisesta muodikasta.

Vuoden ensimmäisessä Politiikka-lehden numerossa tarkastelu suunnataan luottamukseen, epäluottamukseen, osallistumiseen ja tietoon. Artikkelissaan "Luottamuksen kääntöpuoli. Poliittisen epäluottamuksen typologia ja teoreettinen viitekehys" Paul-Erik Korvela ja Isak Vento tarttuvat vähälle huomiolle jääneeseen poliittisen epäluottamuksen käsitteeseen ja erittelevät sitä. Heidän mukaansa niin sokea luottamus johtajiin kuin laajamittainen poliittiseen järjestelmään kohdistuva epäluottamuskin ovat tuhoisia liberaalidemokratialle. Demokratia edellyttää kriittisiä kansalaisia toimiakseen, ja sekä luottamus että epäluottamus vaikuttavat osaltaan siihen, kuinka paljon ja millä tavoilla kansalaiset osallistuvat poliittiseen päätöksentekoon. 
Demokratian kehittämiselle olisi tärkeää laajentaa osallistumismuotoja ja lisätä niiden vaikutusta edustukselliseen päätöksentekoon, jotta uudenlaiset osallistumisen muodot eivät jäisi irralliseksi näennäisosallistumiseksi. Mikko Värttö, Maija Jäske, Kaisa Herne ja Kimmo Grönlund ovat tutkineet kaupunginvaltuutettujen osallistumista Turun kaupungin kanssa yhteistyössä järjestettyyn kansalaispaneeliin. Artikkelissaan "Kaksisuuntainen katu. Poliitikot osallistujina puntaroivassa kansalaiskeskustelussa" he toteavat, että osallistuminen paneeliin tarjosi poliitikoille tietoa kaupunkilaisten mielipiteistä mutta ei silti muuttanut heidän alkuperäisiä kantojaan käsiteltävästä asiasta. Valtuutetut suhtautuivat kuitenkin myönteisesti ajatukseen paneelien käytöstä valtuustotyön tukena. Kirjoittajat ehdottavat, miten kansalaispaneelien järjestelyjä voisi jatkossa parantaa, jotta ne edustaisivat kuntalaisia paremmin ja kanavoisivat näiden näkemyksiä päätöksentekoon tehokkaammin.

Tieteen ja tutkimuksen vapauden ohella olennaista on myös tutkimustiedon vaikuttavuus ja sen hyödyntäminen poliittisessa päätöksenteossa. Anne Maria Holli ja Saara Turkka tarkastelevat artikkelissaan tutkijoiden osallistumista keskeisiin päätöksenteon valmistelun instituutioihin, valtionkomiteoihin ja ministeriöiden laajapohjaisiin valmistelutyöryhmiin. Heidän artikkelinsa "Tieteen muuttuva rooli korporatistisessa neuvonannossa. Pitkittäisanalyysi tutkijoiden asemasta ministeriöiden valmistelutyöryhmissä 1980-2018” osoittaa, että tutkijoiden osuus työryhmissä on 2010-luvulla vähintäänkin puolittunut sitten vuosituhannen lopun. Samalla myös heidän asemansa työryhmien sisäisessä hierarkiassa, erityisesti niiden puheenjohtajina, on heikentynyt. Suomessa ei näin ollen ole tapahtunut joissakin muissa Pohjoismaissa havaittua "tieteellistymiskehitystä", vaan päinvastoin tutkijoiden määrä valmistelukorporatismin instituutioissa on vähentynyt.

Seppo Tiihonen luo Keskustelua-osion puheenvuorossaan "Pääministerin nousu kriisijohtajaksi” katsauksen pääministeri Sanna Marinin rooliin koronakriisin johtamisessa. Useiden hallituskausien aikana monien muutosten myötä kehitetty kriisinjohtamisen malli on edelleen keskeneräinen eivätkä toimivaltasuhteet ole selkeät. Valmiuslain uudistaminen onkin aloitettu uudestaan maaliskuussa 2021 (Sajari 15.3.2021). Puheenvuoron kontekstina olevassa covid-19-pandemiassa on siinäkin kyse tiedosta, osallistumisesta ja luottamuksesta. Päätöksiä koronakriisin hallinnasta on tehtävä muuttuvan, sirpaleisen ja riittämättömän tiedon varassa. Käytännön elämän tasolla pandemian päihittäminen edellyttää kaikkien osallistumista tartuntojen estämiseen. Koronauutisoinnissa luottamus on yksi avainsanoista. On toistuvasti arveltu, että Suomen tilannetta koronakriisissä on helpottanut kansalaisten jo valmiiksi korkea luottamus viranomaisiin, yhteiskunnallisiin instituutioihin ja mediaan.

Luottamus on yksi onnellisen yhteiskunnan salaisuus Heikki Aittokosken (2020) kirjassa Onnellisten saari. Matka täydelliseen yhteiskuntaan. Pekka Kettunen huomauttaa kirja-arviossaan, että kansalaisten luottamus siihen, että poliittinen päätöksenteko kohtelee kansalaisia tasapuolisesti, voi myös heiketä. Aittokosken kirjassa korostetaan luottamuksen lisäksi myös kansalaisten osallistumista hyvinvointivaltion ylläpitämiseen esimerkiksi veroja maksamalla. Yhtenä osallistumisen areenana siinä kuvataan Botswanassa toimivaa kgotla-instituutiota - eräänlaisia kansankokouksia, joihin osallistuminen on kansalaisille tärkeää. Äskettäin neljättä kertaa maailman onnellisimmaksi valtioksi valitussa Suomessa arvokasta on Aittokosken mukaan etenkin ne hyvinvointivaltion rakenteet, jotka pyrkivät takaamaan kaikille lapsille mahdollisuuden kasvaa ja kehittää itseään. Kirjaesittely päättyykin valoisaan näkymään siitä, että tällä hetkellä suurin osa maailman lapsista käy koulua. 


\section{LÄHTEET}

Aittokoski, Heikki. 2020. Onnellisten saari. Matka täydelliseen yhteiskuntaan. Helsinki: Sanoma.

Ampuja, Marko ja Poutanen, Mikko. 2020. Trollaus poliittisena viestintästrategiana ja liberaalin demokratian kriisioireena. https://politiikasta.fi/trollaus-poliittisena-viestintastrategiana-ja-liberaalidemokratian-kriisioireena/. Viitattu 22.3.2021.

Chadwick, Andrew. 2013. The Hybrid Media System. Politics and Power. Oxford ja New York: Oxford University Press.

Kervinen, Elina. 18.3.2021. Nato-raportin mukaan Suomen hallitukseen on kohdistunut laajaa naisvihamielistä verkkohäirintää - Marin: "Kyllä, naiset johtavat hallitusta. Get over it." Helsingin Sanomat. https://www.hs.fi/politiikka/art-2000007868192.html. Viitattu 25.3.2021.

Ruotsalainen, Maria. 2017. "Vihapuheen" nousu julkisessa keskustelussa. Teoksessa Emilia Palonen ja Tuija Saresma (toim.), Jätkät ja jytkyt. Perussuomalaiset ja populismin retoriikka. Tampere: Vastapaino, 181-197.

Sajari, Petri. 15.3.2021. Oikeusministeriö alkaa selvittää valmiuslain muuttamista. Helsingin Sanomat. https://www.hs.fi/politiikka/art-2000007861850.html. Viitattu 25.3.2021.

Statcom. 2021. Abuse of power: coordinated online harassment of Finnish government ministers. https:// www.stratcomcoe.org/abuse-power-coordinated-online-harassment-finnish-government-ministers. Viitattu 25.3.2021.

Vaarakallio, Tuula. 2017. Perussuomalaisten kaksoispuhe. Teoksessa Emilia Palonen ja Tuija Saresma (toim.), Jätkät ja jytkyt. Perussuomalaiset ja populismin retoriikka. Tampere: Vastapaino, 199-217.

Väliverronen, Esa ja Ekholm, Kai (toim.). 2020. Tieteen vapaus ja tutkijan sananvapaus. Tampere: Vastapaino. 